\title{
Effect of debranning process on deoxynivalenol content in whole- wheat flours
}

\author{
Casiane Salete Tibola $^{1}$ (D) | Eliana Maria Guarienti ${ }^{1}$ | Alvaro Renato Guerra Dias $^{2}$ | \\ Marcio Nicolau $^{1}$ | Rafaela Julyana Barboza Devos ${ }^{3}$ | Daniela Dalbosco Teixeira ${ }^{4}$
}

${ }^{1}$ Embrapa Wheat, Passo Fundo, Brazil

${ }^{2}$ Department of Agroindustrial Science and Technology, Federal University of Pelotas, Capão do Leão, Brazil

${ }^{3}$ Food Engineering, University of Passo Fundo, Passo Fundo, Brazil

${ }^{4}$ Chemical Engineering, University of Passo Fundo, Passo Fundo, Brazil

\section{Correspondence}

Casiane Salete Tibola, Embrapa Wheat, Rodovia BR 285, Km 294 - C.P. 3081 Passo Fundo, RS 99050-970, Brazil.

Email: casiane.tibola@embrapa.br

Funding information

CNPq, Project Number: 473177/2014-5

\begin{abstract}
Background and objectives: Post-harvest mitigation strategies are essential to reduce mycotoxin contamination in wheat-based foods. The study aimed to evaluate the effect of the debranning process on the deoxynivalenol content in whole-wheat flour naturally contaminated by Fusarium spp. Thirty commercial wheat samples were used and were obtained in Southern Brazil Region in 2015 crop season.

Findings: The highest DON contamination level was found in the no-debranned samples and the outermost fraction (extraction rate $>95 \%$ ), which corresponds to the debranning time of $15 \mathrm{~s}$. When all debranning times were included in the analysis, only the samples from Paraná State had the DON content significantly reduced after the debranning.
\end{abstract}

Conclusions: The debranning process reduced the DON content in whole-wheat flour with lower to moderate levels of contamination, corresponding to DON content of 1.032 and $1.174 \mu \mathrm{g} / \mathrm{kg}$, obtained in Paraná and Rio Grande do Sul States, respectively.

Significance and novelty: These results are important for wheat supply chain to meet the legislation requirements and to produce safer foods.

\section{K E Y W O R D S}

ash content, debranning process, mycotoxins, whole-wheat flour

\section{$1 \mid$ INTRODUCTION}

Most of the wheat growing area in Brazil is located in the southern region in the Paraná (50\%) and Rio Grande do Sul (36\%) States (CONAB, 2018). The current domestic production supplies half of the national demand of approximately 10.3 million tons annually (USDA, 2018).

Mycotoxins are poisonous compounds produced by certain species of fungi found in contaminated grains (Neme \& Mohammed, 2017). In Southern Brazil, Fusarium head blight (FHB) is caused by the Fusarium graminearum species, which produces deoxynivalenol (DON) and zearalenone (ZON) mycotoxins (Del Ponte et al., 2015). DON is the most critical mycotoxin because of its widespread occurrence and high concentration in wheat grains. DON disrupts normal cell function, which results in protein synthesis inhibition and affects cell signaling, differentiation, and proliferation in humans and animals (Vidal, Marín, Morales, Ramos, \& Sanchis, 2014).

In the post-harvest stage, the cleaning, aeration, debranning, and milling processes influence the distribution of mycotoxins in wheat fractions. Mycotoxins tend to be concentrated in outer fractions (bran, flour shorts screenings, and middlings) and lower in inner fractions intended for human consumption-flour or semolina (Cheli, Pinotti, Rossi, $\&$ Dell'Orto, 2013). However, this mycotoxin distribution 
pattern is highly variable in wheat milled fractions. The main factors for these conflicting results may be due to the type of mycotoxin (hydrophilic/hydrophobic), the genotype, the level and time of fungal contamination, and the post-harvest procedures (Cheli et al., 2013; Tibola, Fernandes, Guarienti, \& Nicolau, 2015).

More recently, Khaneghah, Martins, Hertwig, Bertoldo, $\&$ Sant'Ana (2018) discussed the fate of DON throughout the processing of wheat, bread, and pasta and accessed data on the impact of specific steps of processing on DON contents in wheat-based products. The authors stated that it has been contradictory data, regarding the fate of DON during wheat and wheat-based products processing, due to factors as temperature, additives, processing time, and loaf size in addition to the occurrence of modified (masked) forms of DON.

Whole-wheat flour is a good source of dietary fiber and antioxidants, which can promote health benefits toward several chronic diseases usually associated with oxidative stress (Yu, 2008). However, the presence of natural and synthetic contaminants in the most external layers poses a risk for consumer safety and need to be taken into serious consideration (Zanoletti et al., 2017). The bran is the wheat fraction most heavily contaminated with DON, which represents a significant concern because this fraction is widely employed to produce feed for animals as well as raw material for whole food products (Khaneghah et al., 2018).

Debranning process, which consists of mild friction (kernel to kernel) and abrasion (kernel to a rough surface), can represent a valuable strategy to maximize the health benefits of cereal-based foods (Ciccoritti et al., 2017). The milling industry is increasingly recognizing debranning or pearling as a useful technology for improving the milling efficiency (Beta, Nam, Dexter, \& Sapirstein, 2005; Meng, Xiao-hong, Xiu-li, $\&$ Shao-xia, 2017). The degree of debranning could be carefully modulated in order to separate the outermost fractions, which could be characterized by a higher content in contaminants and coarse fiber, from the intermediate fractions, which offer potentially high health benefits (Blandino et al., 2013; Giordano et al., 2017; Sovrani et al., 2012). Beta et al. (2005) stated that debranning is a useful technique to obtain wheat bran fractions enriched in phenolics and antioxidants compounds, thereby maximizing health benefits associated with wheat-based products.

Furthermore, Giordano and Blandino (2018) proposed debranning of wheat to reduce the contamination by arsenic, lead, and cadmium to avoid any potential risk for the health of consumers. Cheli et al. (2010) investigated the distribution of deoxynivalenol, cadmium, and lead in wheat milling fractions obtained by conventional milling and debranning before milling. In another experiment, Cheli et al. (2013) also explored the effect of debranning on wheat mycotoxin content. The authors reported that debranning efficiency is hugely variable, ranging from $15 \%$ to $78 \%$ of DON reduction, using both laboratory and industrial scales. Therefore, it is essential to explore the effects of debranning in the wheat mycotoxin reduction, especially in wheat lots with high DON contamination levels.

The objective of this study was to evaluate the effect of the debranning process on the deoxynivalenol content in wholewheat flour naturally contaminated by Fusarium spp, to enhance the safety of whole-wheat products.

\section{\begin{tabular}{l|l}
2 & METHODOLOGY
\end{tabular}}

\section{1 | Sampling characterization}

Thirty commercial wheat samples, representing mainly bread wheat and domestic wheat, according to Brazilian wheat classes, were used in this work (Brasil, 2010). The wheat samples were naturally contaminated by Fusarium spp, and it was obtained in Southern Brazil Region, in 2015 crop season. The geographical origin of these cultivars was Paraná (19 samples), Rio Grande do Sul (nine samples), and Santa Catarina (two samples).

In Brazil, the wheat production areas were divided into four homogeneous regions that were defined based on the variables: rainfall, temperature, altitude, and description of grain yield. The southern region comprises the Region 1 (cold, humid, and high elevation); Region 2 (moderately hot, humid, and low elevation); and Region 3 (hot, moderately dry, and low elevation) (Munaro et al., 2014). The origins of the samples in this study were $40 \%$ from Region 1; $47 \%$ from Region 2; and 13\% from Region 3.

The samples were selected based on the initial DON concentrations. It was selected only wheat samples with DON levels above $200 \mu \mathrm{g} / \mathrm{kg}$. The DON content was analyzed by enzyme-linked immunosorbent assay (ELISA) kit (AgraQuant ${ }^{\circledR}$ ).

\section{2 | Debranning and milling procedures}

The grains were polished using a laboratory Zaccaria rice machine (model PAZ-1-DTA), previously regulated for each treatment. The weight of samples fed to the polisher was approximately $50 \mathrm{~g}$. The debranning process was monitored through time control. The treatments were nodebranned kernels and three consecutive debranning times $15 \mathrm{~s}, 30 \mathrm{~s}$, and $60 \mathrm{~s}$ (Table 1). The samples were weighed before and after the debranning procedure. After each debranning passage, the equipment was thoroughly cleaned with dust aspiration and compressed air, to minimize contamination.

Intact grains and grains after each debranned treatment were milled to obtain the whole-wheat flour. The samples were milled in a Laboratory Mill 3,100 (Perten Instruments, 
TA B L E 1 Samples characterization and experimental conditions of the debranning process

\begin{tabular}{|c|c|c|c|c|c|c|}
\hline State & Number of samples & $\begin{array}{l}\text { Debranning } \\
\text { time (s) }\end{array}$ & $\begin{array}{l}\text { Starting kernels } \\
\text { mass }(\mathrm{g})^{\mathrm{a}}\end{array}$ & $\begin{array}{l}\text { Final kernels } \\
\text { mass }(\mathbf{g})^{\mathbf{b}}\end{array}$ & $\begin{array}{l}\text { Mean debranning } \\
\text { level }(\%)^{\mathrm{c}}\end{array}$ & Extraction rates \\
\hline \multirow[t]{2}{*}{ Rio Grande do Sul } & \multirow[t]{2}{*}{9} & 15 & 102.2 & 98.2 & 3.9 & 96.1 \\
\hline & & 60 & 101.1 & 87.5 & 13.5 & 86.5 \\
\hline \multirow[t]{2}{*}{ Santa Catarina } & \multirow[t]{2}{*}{2} & 15 & 97.5 & 93.2 & 4.4 & 95.6 \\
\hline & & 60 & 97.5 & 81.9 & 16.1 & 83.9 \\
\hline \multirow[t]{3}{*}{ Paraná } & \multirow[t]{3}{*}{19} & 15 & 103.2 & 99.2 & 3.9 & 96.1 \\
\hline & & 30 & 103.7 & 96.6 & 6.8 & 93.2 \\
\hline & & 60 & 100.8 & 87.6 & 13.1 & 86.9 \\
\hline
\end{tabular}

${ }^{\text {a }}$ Starting kernel mass $=$ whole kernel mass.

${ }^{\mathrm{b}}$ Final kernels mass $=$ mass after the debranning process.

${ }^{\mathrm{c}}$ Debranning level $\%=($ Final kernel mass $\times 100) /$ Starting kernels mass.

Huddinge, Sweden). Wheat fractions were ground to pass through a $0.8-\mathrm{mm}$ screen.

\section{3 | Deoxynivalenol and technological quality analysis}

\subsection{1 | Deoxynivalenol analysis}

The DON content was determined in whole-wheat flour using a commercial direct competitive enzyme-linked immunosorbent assay (ELISA) kit (AgraQuant $\left.{ }^{\circledR}\right)$. The limit of detection (LOD) and the limit of quantification (LOQ) in this test were $200 \mu \mathrm{g} / \mathrm{kg}$ and $250-5,000 \mu \mathrm{g} / \mathrm{kg}$, respectively. Extraction procedure, calibration, and reading were performed according to manufacturer's instructions. The method was approved by the AOAC Research Institute (Certificate $\left.\mathrm{N}^{\circ} 110,701\right)$. The accuracy, sensitivity, and specificity of the ELISA method compared with a chromatographic method, for mycotoxin analysis, were determined in a previous study (Duffeck, Tibola, Guarienti, \& Del Ponte, 2017).

\subsection{2 | Moisture and protein content}

The moisture and protein contents were determined by nearinfrared reflectance spectroscopy (NIR instrument FOSS XDS-RCA, Hoganas, Sweden). The reference methods used for moisture and protein calibration development were, respectively, method 44-15.02 (AACC, 2010) and method 46-13.01 (AACC, 1999).

\subsection{3 | Ash analysis}

The whole-wheat flour was weighted ( $3 \mathrm{~g}$ ) into crucibles, and then, the samples were placed in a muffle furnace at $900^{\circ} \mathrm{C}$ for two hours and a half. It was incinerated until light gray ash or constant weight was obtained. After cooling, the samples and ash contents were calculated on a dry basis (ICC, 1990).

\subsection{4 | Color}

The whole-wheat flour color was evaluated using colorimeter Minolta, model CR-410. Was used the CIEL*a*b* system, with reading angle of $10^{\circ}$ and illuminant D65, following the manufacturer's instructions.

\section{4 | Statistical analysis}

All the analysis of wheat samples (no-debranned and debranned whole-wheat flour) were in triplicate.

Statistical analyses were performed using R Software 3.5.0 (R Development Core Team, 2018). The linear regression was selected to explain the relationship among debranning times and the deoxynivalenol, protein, ash, color in the whole-wheat flour. The Box-Cox power transformation was used to fix the normality and linearity issues, for deoxynivalenol and protein. For all tests, the statistical significance was set at $p<0.05$.

\section{\begin{tabular}{l|l}
3 & RESULTS
\end{tabular}}

\section{1 | DON content}

The DON content of the whole-wheat flours from Southern Brazilian states is reported in Figure 1. The Box-Cox power transformation that provides the best result for deoxynivalenol was the lambda $=0.1613061$. The highest DON contamination level was found in the no-debranned samples and the outermost fraction (extraction rate $>95 \%$ ), which corresponds to the debranning time of $15 \mathrm{~s}$. 
The debranning times presented effect in the DON reduction and the debranning time of $15 \mathrm{~s}$, which removed the outermost fraction (Table 1), where the most efficient in the reduction of the DON contamination (Figure 1). On average, the DON content decreased by $25 \%, 31 \%$, and $31 \%$ in the debranning times of 15,30 , and $60 \mathrm{~s}$, respectively, compared with no-debranned samples (Figure 1). Related to the States, the consecutive debranning times were effective in reducing DON levels in Paraná and Rio Grande do Sul, only until 30 s; after this, the debranning presented a stable behavior (Figure 2).

When the samples were separated by State of Origin, with all debranning times included $(15,30$, and $60 \mathrm{~s})$, a significant reduction in DON contamination $(p<0.05)$ was found only in the samples from Paraná State (Table 2). In the Santa Catarina State, the DON content decreased after each progressive debranning toward the inner layers, although it was not statistically significant (Table 2).

In Brazil, the upper limits of DON established for wholewheat flour are $1.250 \mu \mathrm{g} / \mathrm{kg}$ (ANVISA, 2017). Considering this level, only the wheat samples from Paraná and Rio Grande do Sul States would meet the mycotoxin regulation, after the debranning process. The DON levels in the wheat samples from Santa Catarina remained above the permitted limit, even after the debranning time of $60 \mathrm{~s}$.

\section{2 $\quad$ Protein content}

Protein content reduced significantly in the debranned samples from Rio Grande do Sul and Paraná (Table 2). In the samples from Santa Catarina, no differences in protein levels were identified due to debranning process (Table 2). The protein content of whole-wheat flours reduced more pronounced
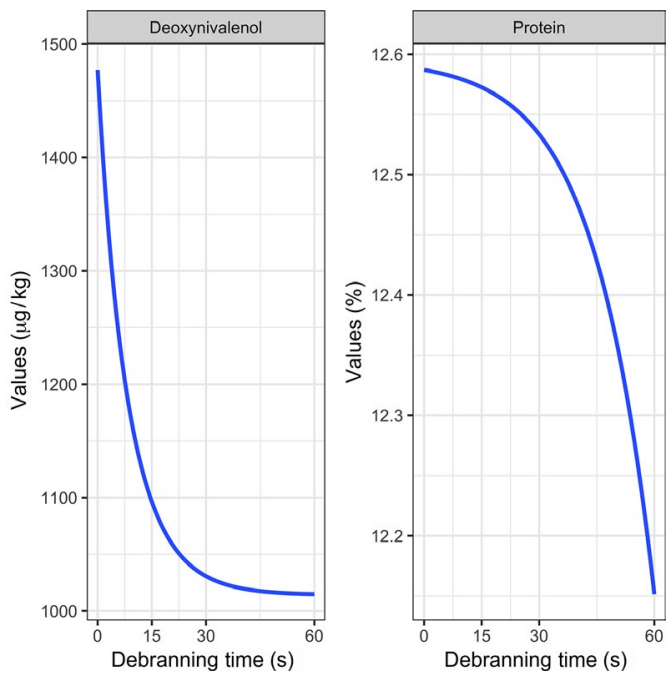

F I G URE 1 Adjusted curves for deoxynivalenol and protein levels of no-debranned and debranning times of 15,30 , and $60 \mathrm{~s}$ for whole-wheat flours [Color figure can be viewed at wileyonlinelibrary. com] after $30 \mathrm{~s}$ of debranning (Figure 1). The Box-Cox power transformation that provides the best result for protein was lambda $=0.4804147$.

\section{3 $\quad$ Ash content}

The ash content reduced significantly in the debranned fractions in all wheat samples evaluated (Table 2). The ash reduction was irrespective of State of Origin (Figure 3).

\subsection{Color $\mathrm{a}^{*}$, $\mathrm{b}^{*}$, and $\mathrm{L}^{*}$}

Color $a^{*}$ (red to green colors) and $b^{*}$ (yellow to blue colors) presented the same pattern of significative reduction in all debranned samples (Table 2 and Figure 3). The parameter Color $L^{*}$, which measures the "lightness," with a score of 100 as white and 0 as black, increased significantly, after the debranning process, in all analyzed samples (Table 2 and Figure 3).

\section{4 | DISCUSSION}

The objective of this study was to evaluate the effect of the debranning process on the deoxynivalenol content in wholewheat flour.

Overall, the highest DON contamination level in all wheat samples was found in the no-debranned samples and the outermost fraction (extraction rate $>95 \%$ ), which corresponds to the debranning time of $15 \mathrm{~s}$. According to Sovrani et al. (2012), deoxynivalenol contamination decreased from the external to the internal layers, $64 \%$ of total contamination of kernel was found in the $0 \%-5 \%$ and $5 \%-10 \%$ fractions.

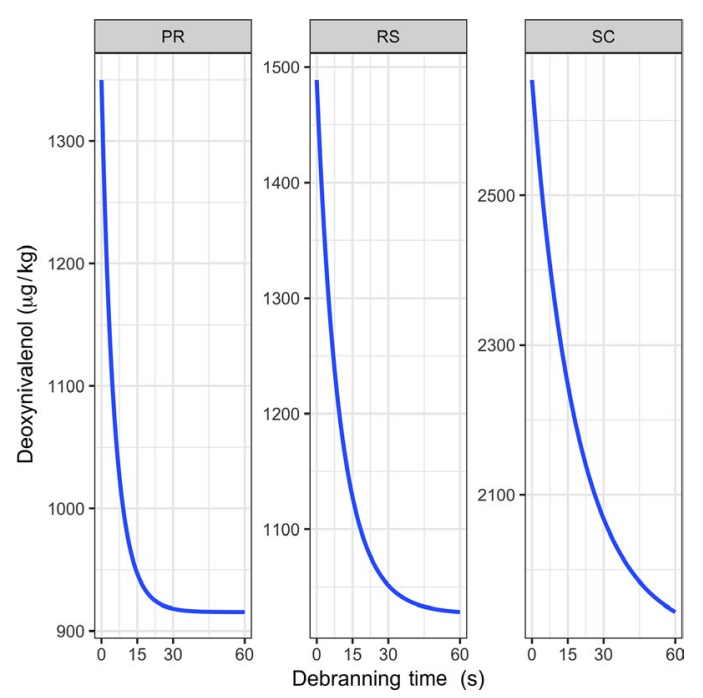

F IG URE 2 Adjusted curves for deoxynivalenol levels by State, of no-debranned and debranning times of 15,30 , and $60 \mathrm{~s}$ for wholewheat flours [Color figure can be viewed at wileyonlinelibrary.com] 
TA B L E 2 Levels of significance of linear regression analyses performed for whole-wheat flours using data of wheat cultivars from Southern Brazil submitted to debranning process

\begin{tabular}{llrrr} 
State & Parameter & Intercept & Debranning time & $\boldsymbol{p}$-value \\
Rio Grande do Sul & Ash & 1.8117 & $\mathbf{- 0 . 0 0 6 6}$ & 0.0000 \\
& Color_a & 3.6212 & $\mathbf{- 0 . 0 2 1 3}$ & 0.0000 \\
& Color_b & 11.9234 & $\mathbf{- 0 . 0 3 1 4}$ & 0.0000 \\
& Color_L & 80.4711 & $\mathbf{0 . 0 7 8 3}$ & 0.0000 \\
& Deoxynivalenol & 6.9479 & $\mathbf{- 0 . 0 0 4 9}$ & 0.1434 \\
& Protein & 12.3213 & $\mathbf{- 0 . 0 0 7 7}$ & 0.0354 \\
Santa Catarina & Ash & 1.7600 & $\mathbf{- 0 . 0 0 7 0}$ & 0.0000 \\
& Color_a & 3.2570 & $\mathbf{- 0 . 0 2 1 3}$ & 0.0000 \\
& Color_b & 11.7020 & $\mathbf{- 0 . 0 3 7 5}$ & 0.0000 \\
& Color_L & 80.4827 & $\mathbf{0 . 0 6 9 1}$ & 0.0000 \\
& Deoxynivalenol & 7.7447 & $\mathbf{- 0 . 0 0 4 7}$ & 0.2455 \\
& Protein & 11.9350 & -0.0088 & 0.4380 \\
Paraná & Ash & 1.8002 & $\mathbf{- 0 . 0 0 5 9}$ & 0.0000 \\
& Color_a & 3.7048 & $\mathbf{- 0 . 0 2 1 7}$ & 0.0000 \\
& Color_b & 12.0925 & $\mathbf{- 0 . 0 3 3 4}$ & 0.0000 \\
& Color_L & 80.0154 & $\mathbf{0 . 0 7 5 0}$ & 0.0000 \\
& Deoxynivalenol & 6.8203 & $\mathbf{- 0 . 0 0 6 0}$ & 0.0085 \\
& Protein & 12.8911 & $\mathbf{- 0 . 0 0 7 2}$ & 0.0080 \\
\hline
\end{tabular}

Note: Significant values were reported in bold style $(p<0.05)$. $p$-Value corresponds to the significance of debranning time factor.

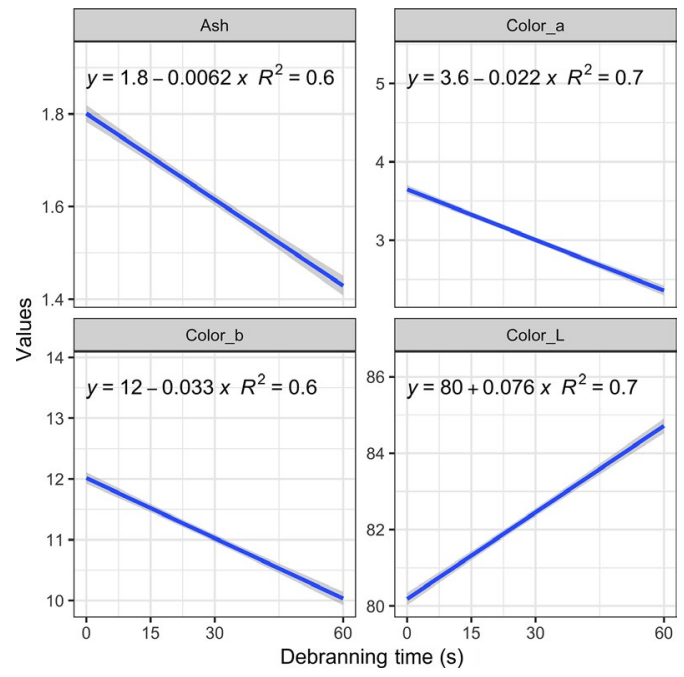

F I G URE 3 Linear models for ash content and colors parameters, with the coefficient of determination $\left(R^{2}\right)$ and equations, in wholewheat flours [Color figure can be viewed at wileyonlinelibrary.com]

In Santa Catarina and Rio Grande do Sul States, the DON content does not reduce significantly after the debranning process when all debranning times were included in the analysis (Table 2). Similarly, Cheli et al. (2010) reported that debranning reduced, although not significantly, the levels of DON in semolina when compared with conventional milling. These findings might be accounted for the heterogeneity of mycotoxin distribution in wheat grains (Cheli et al., 2013; Savi, Piacentini, Tibola, \& Scussel, 2014). Edwards, Kharbikar, Dickin, MacDonald and Scudamore (2018) reported that repeated wetting and drying could cause movement of DON toward equilibrium across the milling fractions, whereas high levels of rainfall could cause reduction of DON in the bran fraction, resulting in a proportional increase within the white flour.

The mean DON content for Paraná, Rio Grande do Sul, and Santa Catarina States was 1.032, 1.174, and $2.228 \mu \mathrm{g} / \mathrm{kg}$, respectively. Therefore, the debranning process was effective only in the lower to moderate levels of DON contamination. Different from our results, Ríos, Pinson-Gadais, Abecassis, Zakhia-Rozis, \& Lullien-Pellerin (2009) concluded that debranning demonstrated as an efficient process, at least at the laboratory scale, to remove both Fusarium and DON irrespective of the initial level of mycotoxins in grains. Contrary to our findings, Aureli and D'Egidio (2007) detected for higher contaminated grain samples, a more pronounced reduction in the DON contamination of durum wheat semolina and flour (and of pasta produced from that) due to debranning before milling.

The debranning time of $60 \mathrm{~s}$ that removed 10\%-16.1\% (extraction rate between $83 \%$ and $87 \%$ ), of the grain mass, was less effective in reducing DON content (31\%) when compared with other debranning times ( $15 \mathrm{~s}$ and $30 \mathrm{~s}$ ). The mean reduction was equivalent to the time of $30 \mathrm{~s}$ and very similar to the reduction obtained with $15 \mathrm{~s}$ of debranning (25\%). Our 
results for DON were similar to those reported by Sovrani et al. (2012). The authors stated that DON decreases moving from the external to the internal layers following a biphasic behavior, and a high reduction was observed in the first debranning steps and a slower decrease followed this.

The main weather characteristics in Southern Brazil for the 2015 spring season were described in Guarienti et al. (2017). In Rio Grande do Sul State, the wheat crops sown late were more intensely affected by the excess rainfall in the spring season. In Santa Catarina, was registered continued rainfall during most of October in 2015 season (Guarienti et al., 2017). The various number of days with excessive moisture associated with warmer temperatures at the heading stage of wheat crop development favored fungal diseases such as Fusarium spp (Tibola, Fernandes, \& Guarienti, 2016).

Edwards et al. (2011) reported that DON concentration in flour fractions was equivalent to that of the milled wheat, with a lower concentration in outer layers (bran), in the wheat from a season characterized by high pre-harvest rainfall. This unexpected behavior resulted from the movement of DON to inner layers due to the DON highly solubility in water (Edwards et al., 2011). A more recent study indicated that DON is highly mobile within the grain and can migrate between grain structures and be leached from the grain pre-harvest resulting in varying distributions across milled fractions in post-harvest (Edwards et al., 2018). On the other hand, Tibola et al. (2015) reported that the higher levels of mycotoxin were more likely to occur due to the fungal growth in the inner grain layers, promoted by the ideal conditions for fungal infection, than mycotoxin diffusion among grain layers.

The debranning process does not remove the outer kernel tissues homogeneously, as abrasion affects especially the accessible parts of the kernels (De Brier et al., 2015). Wheat bran debranning fractions with different proportions of pericarp and aleurone can be produced (Hemdane et al., 2016). Further, also within the endosperm fractions, the extent of contamination with mycotoxins can vary. Usually, the outer layers (bran) of the wheat grain contain higher levels of Fusarium mycotoxins (Savi et al., 2016; Tibola et al., 2016, 2015). However, a correlation between the DON content and the ash content, as a marker for bran particles, was not found (Ríos et al., 2009; Schaarschmidt, \& Fauhl-Hassek, 2018).

Overall, the debranning time of $15 \mathrm{~s}$ was the most effective in the DON reduction, approximately $500 \mu \mathrm{g} / \mathrm{kg}$, when all samples were considered (Figure 1). According to Santos et al. (2013), the mean DON content in wheat from Paraná State was $1894.9 \mu \mathrm{g} / \mathrm{kg}$. Savi et al. (2016) analyzed wheat samples from Southern Brazil and reported that the bran fraction had the highest mean concentration of DON $(2,278 \mu \mathrm{g} /$ $\mathrm{kg})$, followed by milled wheat and finished flour $(1895 \mu \mathrm{g} /$ $\mathrm{kg}$ and $1,305 \mu \mathrm{g} / \mathrm{kg}$ ). These data highlight how stable DON is to wheat and its products, reinforcing the importance of pre- and post-harvest strategies to diminish human exposure to DON.

Protein content reduced significantly with the consecutive debranning time in the samples from Rio Grande do Sul and Paraná States (Table 2). Figure 1 shows a reduction of the protein content with the increase in extraction rates. These results are mostly explained by the higher concentration of the protein in the outermost parts of the grain (pericarp and aleurone layers), which represent about 20\% of the total proportion of proteins in the grain (Brouns, Hemery, Price, \& Anson, 2012). The aleurone is relatively rich in proteins and minerals (Delcour \& Hoseney, 2010; De Brier et al., 2015).

Similar results were reported by Azizi, Sayeddin, and Payghambardoost (2006) that studied eight rates of wheat flour extraction (from 70\% to 93\%). Another study conducted by Mueen-ud-Din, Rehman, Anjum, Nawaz, and Murtaza (2010), tested four different extraction rates (from 64\% to $100 \%$ ), also reported protein reduction.

According to Sarkar and Dexter (2016), the germ and bran proteins are non-gluten proteins that have better nutritional value than gluten proteins but are not beneficial to processing properties. Besides, bran contains most of the fiber in the kernel, which is an essential nutritional compound.

Similarly, to our results of protein in Santa Catarina State (Table 2), De Brier et al. (2015) did not report significant differences in protein content after pearling process.

In our study, moisture content was not significantly affected by debranning (ranging from $10.8 \%$ to $13.9 \%$ ).

As expected, the ash content reduced significantly with the progressive removal of external layers of wheat grains by debranning (Table 2 and Figure 3). The highest concentration of minerals is located in the outermost layers of the grainspericarp and aleurone layer (Belitz \& Grosch, 1997). Other studies reported the same pattern (Ciccoritti et al., 2017; De Brier et al., 2015). Ash contents ranged from 3.3\% to $4.2 \%$ in the flours obtained from debranned kernels and were thus lower than that of regular bran (6.1\%) (De Brier et al., 2015).

Color $a^{*}$ (red to green colors) and $b^{*}$ (yellow to blue colors) presented the same pattern of significative reduction in all debranned samples (Table 2 and Figure 3). Otherwise, the parameter Color $L^{*}$, which measures the "lightness," increased significantly, after the debranning process, in all analyzed samples (Table 2 and Figure 3). This result was expected since a higher percentage of pigments that give color to the wheat are located in the outer layers of the grains. According to Lachman, Martinek, Kotíkov, Orsak, and Sulc (2017), anthocyanins are accumulated in the aleurone or pericarp layer and give blue, purple, or the combination of these colors, whereas flavonoids, such as yellow C-glycosides of flavones, flavonols, flavanonols, proanthocyanidins, and reddish-colored phlobaphenes are mainly concentrated in the outer layers of the grains. 
Further studies involving a higher number of samples, especially with high DON contamination levels and different debranning conditions, would be important to explain the effects of the debranning process in the mycotoxin distribution in wheat products.

\section{5 | CONCLUSIONS}

The debranning process reduced the DON content in wholewheat flour with lower to moderate levels of contamination, corresponding to DON content of $1.032 \mu \mathrm{g} / \mathrm{kg}$ and $1.174 \mu \mathrm{g} /$ kg, obtained in Paraná and Rio Grande do Sul States, respectively. Debranning levels of 5\% guaranteed low starch losses and, at the same time, noticeably reduced the DON contamination of the kernels. Therefore, the debranning process can be a complementary strategy to reduce DON contamination and to produce safer wheat-based products.

\section{ACKNOWLEDGMENTS}

We are grateful for the financial support for this study provided by Embrapa (02.14.01.012.00.00) and CNPq project 473177/2014-5.

\section{ORCID}

Casiane Salete Tibola (D) https://orcid. org/0000-0003-2036-8163

\section{REFERENCES}

American Association of Cereal Chemists (1999). Approved methods of the AACCI. St. Paul, MN: The Association.

American Association of Cereal Chemists (2010). Approved methods of the AACCI. St. Paul, MN: The Association.

ANVISA (2017). Regulation on tolerable maximum levels (LMT) for deoxynivalenol in food. RDC Resolution n. 138. Approved February 08, 2017. Brasília, DF: Agência Nacional de Vigilância Sanitária. http://portal.anvisa.gov.br/legislacao/?inheritRedirect=true\#/visua lizar/34045

Aureli, G., \& D'Egidio, M. G. (2007). Efficacy of debranning on lowering of deoxynivalenol (DON) level in manufacturing processes of durum wheat. Tecnica Molitoria, 58, 729-733.

Azizi, M. H., Sayeddin, S. M., \& Payghambardoost, S. H. (2006). Effect of flour extraction rate on flour composition, dough rheological characteristics and quality of flat bread. Journal of Agricultural Science and Technology, 8, 323-330.

Belitz, H.-D., \& Grosch, W. (1997). Química de los alimentos, 2nd ed. Zaragoza: Editorial Acribia S.A.

Beta, T., Nam, S., Dexter, J. E., \& Sapirstein, H. D. (2005). Phenolic content and antioxidant activity of pearled wheat and roller-milled fractions. Cereal Chemistry, 82, 390-393. https://doi.org/10.1094/ CC-82-0390
Blandino, M., Sovrani, V., Marinaccio, F., Reyneri, A., Rolle, L., Giacosa, S., ... Arlorio, M. (2013). Nutritional and technological quality of bread enriched with an intermediated pearled wheat fraction. Food Chemistry, 141, 2549-2557. https://doi.org/10.1016/j. foodchem.2013.04.122

Brazil (2010). Ministry of Agriculture, Livestock and Supply. Normative Instruction $\mathrm{n}^{\circ} 38$, of November 30, 2010. Technical regulation of wheat. Official Gazette [of] Federative Republic of Brazil, Brasília DF, n. 29, p. 2, 1 dez. 2010. Section 1. Available at http://www.agricultura.gov.br/

Brouns, F., Hemery, Y., Price, R., \& Anson, N. M. (2012). Wheat aleurone: Separation, composition, health aspects, and potential food use. Critical Reviews in Food Science and Nutrition, 52, 553-568. https://doi.org/10.1080/10408398.2011.589540

Cheli, F., Campagnoli, A., Ventura, V., Brera, C., Berdini, C., Palmaccio, E., \& Dell'Orto, V. (2010). Effects of industrial processing on the distributions of deoxynivalenol, cadmium and lead in durum wheat milling fractions. Food Science and Technology, 43, 1050-1057. https://doi.org/10.1016/j.lwt.2010.01.024

Cheli, F., Pinotti, L., Rossi, L., \& Dell'Orto, V. (2013). Effect of milling procedures on mycotoxin distribution in wheat fractions: A review. Food Science and Technology, 54, 307-314. https://doi. org/10.1016/j.1wt.2013.05.040

Ciccoritti, R., Taddei, F., Nicoletti, I., Gazza, L., Corradini, D., D'Egidio, M. G., \& Martini, D. (2017). Use of bran fractions and debranned kernels for the development of pasta with high nutritional and healthy potential. Food Chemistry, 225, 77-86. https:// doi.org/10.1016/j.foodchem.2017.01.005

CONAB (2018). Brazilian crop-grains. Safra 2017/2018, Fifth survey/ February 2018, 5(5), Companhia Nacional de Abastecimento. http:// www.conab.gov.br/conteudos.php?a=1253\&t

De Brier, N., Hemdane, S., Dornez, E., Gomand, S. V., Delcour, J. A., \& Courtin, C. M. (2015). Structure, chemical composition and enzymatic activities of pearlings and bran obtained from pearled wheat (Triticum aestivum L.) by roller milling. Journal of Cereal Science, 62, 66-72. https://doi.org/10.1016/j.jcs.2014.12.009

Del Ponte, E. M., Spolti, P., Ward, T. J., Gomes, L. G., Nicolli, C. P., Kuhnem, P. R., ... Tessmann, D. J. (2015). Regional and field-specific factors affect the composition of Fusarium head blight pathogens in subtropical no-till wheat agroecosystem of Brazil. Phytopathology, 105, 246-254. https://doi.org/10.1094/ PHYTO-04-14-0102-R

Delcour, J. A., \& Hoseney, R. C. (2010). Principles of cereal science and technology, 2nd ed. Saint Paul: AACC International.

Duffeck, M. R., Tibola, C. S., Guarienti, E. M., \& Del Ponte, E. M. (2017). Survey of mycotoxins in Southern Brazilian wheat and evaluation of immunoassay methods. Scientia Agricola, 74, 343-348. https://doi.org/10.1590/1678-992x-2016-0263

Edwards, S. G., Dickin, E. T., MacDonald, S., Buttler, D., Hazel, C. M., Patel, S., \& Scudamore, K. A. (2011). Distribution of Fusarium mycotoxins in UK wheat mill fractions. Food Additives and Contaminants, 28, 1694-1704. https://doi.org/10.1080/19440049.2011.605770

Edwards, S. G., Kharbikar, L. L., Dickin, E. T., MacDonald, S., \& Scudamore, K. A. (2018). Impact of pre-harvest rainfall on the distribution of Fusarium mycotoxins in wheat mill fractions. Food Control, 89, 150-156. https://doi.org/10.1016/j.foodcont.2018.02.009

Giordano, D., \& Blandino, M. (2018). Arsenic, lead and cadmium distribution in the pearled fractions of different winter wheat cultivars (Triticum aestivum L.). Journal of Cereal Science, 80, 94-101. https://doi.org/10.1016/j.jcs.2018.02.002 
Giordano, D., Locatelli, M., Travaglia, F., Bordiga, M., Reyneri, A., Coïsson, J. D., \& Blandino, M. (2017). Bioactive compound and antioxidant activity distribution in roller-milled and pearled fractions of conventional and pigmented wheat varieties. Food Chemistry, 233, 483-491. https://doi.org/10.1016/j.foodchem.2017.04.065

Guarienti, E. M., de Miranda, M. Z., da Cunha, G. R., Nicolau, M., Tibola, C. S., Forcellini, S., ... Lima, M. V. D. (2017). Technological quality of wheat harvested and stored in Brazil - harvest 2015. Passo Fundo: Embrapa Wheat. http://ainfo.cnptia.embrapa.br/digit al/bitstream/item/164643/1/ID44103-2017DO170.pdf

Hemdane, S., Langenaeken, N. A., Jacobs, P. J., Verspreet, J., Delcour, J. A., \& Courtin, C. M. (2016). Study of the intrinsic properties of wheat bran and pearlings obtained by sequential debranning and their role in bran-enriched bread making. Journal of Cereal Science, 71, 78-85. https://doi.org/10.1016/j.jcs.2016.08.003

ICC (1990). Determination of ash in cereals and cereal products. ICC-Standard 104/1. Approved 1960, Revised 1990. Vienna: International Association for Cereal Chemistry.

Khaneghah, A. M., Martins, L. M., von Hertwig, A. M., Bertoldo, R., \& Sant'Ana, A. S. (2018). Deoxynivalenol and its masked forms: Characteristics, incidence, control and fate during wheat and wheat based products processing - A review. Trends in Food Science \& Technology, 71, 13-24. https://doi.org/10.1016/j.tifs.2017.10.012

Lachman, J., Martinek, P., Kotíkov, Z., Orsak, M., \& Sulc, M. (2017). Genetics and chemistry of pigments in wheat grain - a review. Journal of Cereal Science, 74, 145-154. https://doi.org/10.1016/j. jcs.2017.02.007

Meng, L., Xiao-hong, T., Xiu-li, L., \& Shao-xia, W. (2017). Effect of Zn application methods on $\mathrm{Zn}$ distribution and bioavailability in wheat pearling fractions of two wheat genotypes. Journal of Integrative Agriculture, 16, 1617-1623. https://doi.org/10.1016/S2095-3119(17)61657-5

Mueen-Ud-Din, G., Salim-Ur-Rehman Anjum, F. M., Nawaz, H. \& Murtaza, M. A. (2010). Effect of wheat flour extraction rates on flour composition, farinographic characteristics and sensory perception of sourdough naans. International Journal of Nutrition and Food Engineering, 4, 668-674.

Munaro, L., Benin, G., Marchioro, V., Franco, F., Rossi, R. S., Lemes, C., $\&$ Beche, E. (2014). Brazilian spring wheat homogeneous adaptation regions can be dissected in major mega-environments. Crop Science, 54, 1374-1383. https://doi.org/10.2135/cropsci2013.06.0365

Neme, K., \& Mohammed, A. (2017). Mycotoxin occurrence in grains and the role of postharvest management as mitigation strategies, a review. Food Control, 78, 412-425. https://doi.org/10.1016/j.foodc ont.2017.03.012

R Development Core Team (2018). E: The R project for statistical computing, version 3.5.0. Vienna: R Foundation for Statistical Computing. http://www.R-project.org

Ríos, G., Pinson-Gadais, L., Abecassis, J., Zakhia-Rozis, N., \& Lullien-Pellerin, V. (2009). Assessment of dehulling efficiency to reduce deoxynivalenol and Fusarium level in durum wheat grains. Journal of Cereal Science, 49, 387-392. https://doi.org/10.1016/j. jcs.2009.01.003

Santos, J. S., Souza, T. M., Ono, E. Y. S., Hashimoto, E. H., Bassoi, M. C., Miranda, M. Z., ... Hirooka, E. Y. (2013). Natural occurrence of deoxynivalenol in wheat from Paraná State, Brazil and estimated daily intake by wheat products. Food Chemistry, 138, 90-95. https ://doi.org/10.1016/j.foodchem.2012.09.100

Sarkar, A. K., \& Dexter, J. E. (2016). Wheat, dry milling. In C. Wrigley, H. Corke, \& C. Walker (Ed.), Encyclopedia of grain science, 2nd. ed. (pp. 363-374). New York: Elsevier. https://doi.org/10.1016/ B0-12-765490-9/00184-1

Savi, G. D., Piacentini, K. C., Tibola, C. S., Santos, K., Maria, G. S., \& Scussel, V. M. (2016). Deoxynivalenol in the wheat milling process and wheat-based products and daily intake estimates for the Southern Brazilian population. Food Control, 62, 231-236. https:// doi.org/10.1016/j.foodcont.2015.10.029

Savi, G. D., Piacentini, K. C., Tibola, C. S., \& Scussel, V. M. (2014). Mycoflora and deoxynivalenol in whole wheat grains (Triticum aestivum L.) from Southern Brazil. Food Additives \& Contaminants: Part B, 7, 232-237. https://doi.org/10.1080/19393 210.2014.898337

Schaarschmidt, S., \& Fauhl-Hassek, C. (2018). The fate of mycotoxins during the processing of wheat for human consumption. Comprehensive Reviews in Food Science and Food Safety, 17, 556593. https://doi.org/10.1111/1541-4337.12338

Sovrani, V., Blandino, M., Scarpino, V., Reyneri, A., Coïsson, J. D., Travaglia, F., ... Arlorio, M. (2012). Bioactive compound content, antioxidant activity, deoxynivalenol and heavy metal contamination of pearled wheat fractions. Food Chemistry, 135, 39-46. https://doi. org/10.1016/j.foodchem.2012.04.045

Tibola, C. S., Fernandes, J. M. C., \& Guarienti, E. M. (2016). Effect of cleaning, sorting and milling processes in wheat mycotoxin content. Food Control, 60, 174-179. https://doi.org/10.1016/j.foodc ont.2015.07.031

Tibola, C. S., Fernandes, J. M. C., Guarienti, E. M., \& Nicolau, M. (2015). Distribution of Fusarium mycotoxins in wheat milling process. Food Control, 53, 91-95. https://doi.org/10.1016/j.foodc ont.2015.01.012

USDA (2018). Wheat. Grain: World markets and trade. Office of Global Analysis. Washington: United States Department of Agriculture.https ://apps.fas.usda.gov/psdonline/circulars/grain-wheat.pdf

Vidal, A., Marín, S., Morales, H., Ramos, A. J., \& Sanchis, V. (2014). The fate of deoxynivalenol and ochratoxin A during the breadmaking process, effects of sourdough use and bran content. Food and Chemical Toxicology, 68, 53-60. https://doi.org/10.1016/j.fct.2014.03.006

Yu, L. L. (2008). Wheat antioxidants. Hoboken and New Jersey: John Wiley \& Sons and Wiley-Interscience.

Zanoletti, M., Parizad, P. A., Lavelli, V., Cecchini, C., Menesatti, P., Marti, A., \& Pagani, M. A. (2017). Debranning of purple wheat: Recovery of anthocyanin-rich fractions and their use in pasta production. Food Science and Technology, 75, 663-669. https://doi. org/10.1016/j.lwt.2016.10.016

\section{SUPPORTING INFORMATION}

Additional supporting information may be found online in the Supporting Information section at the end of the article.

How to cite this article: Tibola CS, Guarienti EM, Dias ARG, Nicolau M, Devos RJB, Teixeira DD. Effect of debranning process on deoxynivalenol content in whole-wheat flours. Cereal Chem. 2019;96:717-724. https://doi.org/10.1002/cche.10168 